\title{
The Effect of Price, Product Design, Product Quality and Brand Image on Purchase Decisions
}

\author{
Purnama Andri Murdapa \\ \{legowoandri@yahoo.co.id\} \\ Administration Management, Akademi Manajemen Administrasi Yogyakarta, Indonesia
}

\begin{abstract}
The purpose of this study is to determine the effect of Price, Product Design, Product Quality and Brand Image on Purchase Decision of Scoopy motorcycles in Yogyakarta. The Population of this study is the consumers of Scoopy motorcycles in Yogyakarta. The research sample is the consumers who have been using Scoopy for at least more than 1 year. This study uses convenience sampling technique, it is a sampling technique based on the convenience factor. The results show that Price, Product Design, Product Quality, and Brand Image influence the Purchase Decision of Scoopy motorcycles in Yogyakarta.
\end{abstract}

Keywords: Price, Product Design, Product Quality, Brand Image, Purchase Decision.

\section{Introduction}

When the consumers are purchasing the product, they usually pay attention to how the quality of the products offered, it is related to the benefits of the products whether they will meet the consumers' needs or not. According to Tjiptono (1997) product quality is a strong point that meets customer expectations. In evaluating it, customers will use their expectations as a standard or reference [1]. Quality products can be delivered through a tangible product characteristic, one of which is benefit of the product. Product quality is the physical condition, function and nature of a product that can satisfy the tastes and needs of consumers satisfactorily according to value of the money that has been spent [2], [3].

Determining price will be a great concern. Basically, price is determined by the cost of the product. If the price set by the producer is right and in accordance with the purchasing power of consumers, then the selection of a certain product will be dropped on that product [4]. If consumers are willing to accept the price, then the product will be accepted by the public. The analysis of design is also increasingly important, because every design created will result in different levels of demand for the product. In most cases, the consumers will demand unique and creative product design [1], [5]-[7].

Brand image represents the overall perception of the brand and it is formed by the information and past experience when the consumers used the brand. Howard (1989) defines an image as a total image of the consumers or targeted customers' mind of a product or brand [8]. Referring to the definition, brand image can be defined as an impression that is thought by consumers and public of a brand as a reflection of the evaluation for the certain brand. The consumers' experience dealing with service providers or products either it is directly or indirectly will affect the image of these providers. The experience of connecting to an organization can give a huge influence in shaping consumer perceptions toward that 
organization. Kandampully \& Suhartono (2000) state that if consumers can feel a good image, their behavioral intentions are positive such as: the desire to repurchase the same brand, increase purchases and wish to recommend the brand to others (a measure of consumer loyalty) [4]. Based on the previous description, it is interesting to do a research on the Influence of Price, Product Design, Product Quality and Brand Image on Purchase Decision of Scoopy Motorcycle in Yogyakarta.

To know the consumers well, companies need to study consumer behavior which is a personification of all the human soul in their daily lives. Perceptions of influence form others and internal motivations will interact to determine the final decision that is considered as the most appropriate one. According to Kotler (2002), consumer behavior is the behavior exposed by consumers in searching for, buying, using, evaluating and spending products and services that they hope will satisfy their needs [9].

According to Dharmmesta and Irawan (2002) defines price as the amount of money (plus some products if possible) needed to get a combination of products and services [3]. Another definition of price which is stated by Tjiptono (2002) explains that price is a monetary unit or other measure (including other goods and services) exchanged in order to obtain ownership rights or use of an item or service [5], [10], [11]. Price is the only element in the marketing mix that generates sales revenue which is flexible and can be measured quickly [12]. If the customer considers that the price is higher than the value of product, they will not buy the product. If consumers assume that the price is lower than the value of the product, they will buy it, but the seller loses the opportunity to make a profit. Therefore marketers must try to understand the reasons of consumers when they are buying the products, and setting prices according to consumer perceptions about the value of the product [13], [14].

The design or shape of the product is a very important attribute to influence consumers so that consumers are interested in and then buy it. Design is one of the aspects in marketing activities which can be an appeal of the product. Design can shape or give attributes to a product, so that it can be a trademark of a product brand. The characteristics of a product will eventually be able to distinguish it from similar products of other brands from competitors [15]. According to Stanton (1995) product design is an aspect to build a product image. Companies are also increasingly aware of the importance of the marketing value of the product design, especially the design of its appearance. Quality has a very important meaning in consumer purchase decisions [16]. If the quality of the product is good, consumers tend to repurchase while if the quality of the product is not as they expected, consumers will switch their purchases to other similar products. According to Goetch and Davis (1994) quality is a dynamic condition related to products, services, people, processes and environments that meet or even beyond the expectation [17]. According to Ahyari (1997) "Quality is the factor contained in an item or result in accordance with the purpose of the goods or results are intended or needed" [18]. While Kotler and Armstrong (2008) explain the quality of the product is the totality of features and characteristics of the product or service that depends on its ability to satisfy the stated or implied needs [13].

Kotler (2002) explains that a brand is a name, term, sign, symbol, design or combination of the things which is intended to identify goods or services from a person or group of sellers and to distinguish them from the products of competitors [12]. A brand will show the signal about the source of the product to the consumers. In addition, the brand protects both consumers and producers from competitors who try to provide products that look identical. The brand is actually a promise of the seller to consistently provide certain features, benefits, and services to the buyer. The best brands provide quality assurance. Where as Wijaya (2008) sees brand image as an overall perception formed from objects based on information and past 
experiences of consumers [19]. Brand image has an influence on consumer purchase decisions. In other words, a good brand image stimulates purchases by simplifying the decision rules.

Here are the results of several previous researches which are related to this study : Rizan, et al. (2017) explained in his research that brand image, price and product design influence purchase decisions, the results obtained are product quality and product design have a significant effect on purchase decisions partially or simultaneously [2][3]. Likewise Saidani, et al. (2013) in their research explained the influence of product quality and product design on purchase decisions, the results have showed that product quality and product design have a significant influence on purchase decisions both partially and simultaneously. Other research related to the effect of product quality on product purchase decisions explained by Handri (2005), the result of his research showed that $56.31 \%$ of respondents stated that they were affected by product quality on purchase decisions [10], [20]. Wibowo and Karimah (2012) in their research explained that television advertising and price variables had a positive and significant impact on the formation of purchase decisions [21]. Brata, et al. (2017) also explained that the variables of brand image and price had a positive and significant impact on the formation of purchase decisions [22].

\section{Research Method}

The population in this study is consumers who use Scoopy motorcycles in Yogyakarta. The sample is consumers who use Scoopy motorcycles for at least more than 1 year. This study uses convenience sampling technique that is sampling based on the convenience factor [23]. The data used in this study are primary data which is obtained directly from the source (Kuncoro, 2003). Primary data in this study are in the form of answers stated by the consumers who become respondents of this study. In this study, researchers used a survey method. The survey method is a method of research carried out by taking samples from a population and using a questionnaire [23]-[26]. The questionnaire was delivered directly by the researcher to the respondents and it was returned to the researcher after they filled it.

Research conceptual models that can be compiled in this research are as follows :

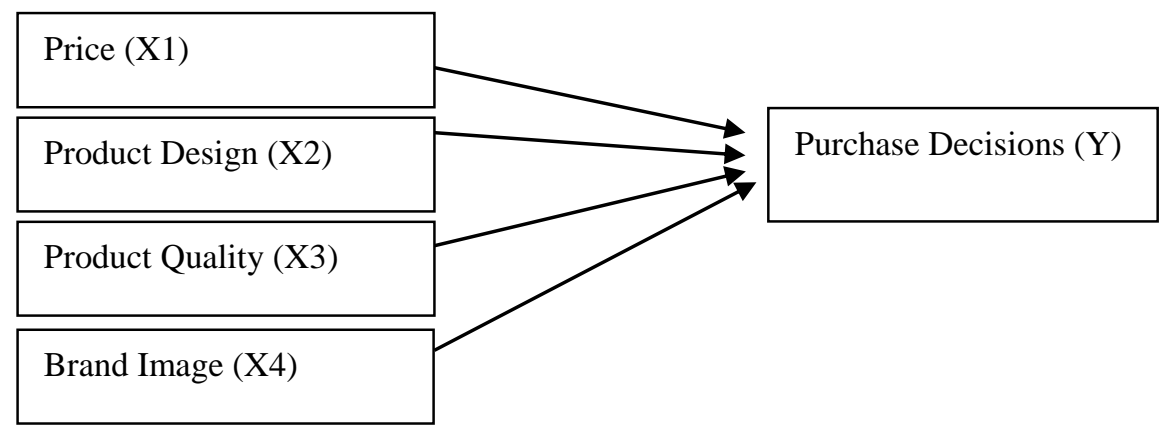

Fig.1. Research Model 
Operational Definitions of Research Variables :

1. Purchase decision (Y), is a consumer's decision as ownership of the actions of two or more alternative choices regarding the process, method, act of buying, by considering other factors about what to buy, when to buy, where to buy and how to pay [27]. The purchase decision indicators in this study are: Brand choice, Design choice, Product quality, Affordable prices, Recommendations from previous buyers.

2. Price (X1), is the amount paid by the buyer to be able to enjoy the benefits of an item.

3. Product design (X2), according to Saidani et al (2008), design is a design pattern that forms the basis of making an object [3].

4. Product quality (X3), according to Kotler and Armstrong (2008), the quality of the product is the totality of features and characteristics of the product or service that depends on its ability to satisfy stated or implied needs [13].

5. Brand image (X4), according to Aaker in Wijaya (2008) brand image is a set of associations that marketers want to create or maintain. These associations state what a brand really is and what is promised to consumers [19].

Based on the research model, the hypotheses that can be arranged are :

$\mathrm{H} 1$ : It is suspected that the price has a positive and significant influence on the decision to purchase a Scoopy motorbike in Yogyakarta.

$\mathrm{H} 2$ : It is suspected that the product design has a positive and significant effect on the decision to purchase a Scoopy motorbike in Yogyakarta.

H3 : It is suspected that product quality has a positive and significant influence on Scoopy motorbike purchase decisions in Yogyakarta.

H4 : It is suspected that the brand image has a positive and significant effect on purchase decisions for Scoopy motorbikes in Yogyakarta.

\section{Result and Discussion}

\subsection{Characteristic of Responden}

Based on the results obtained, the characteristics of respondents can be explained as follows:

Table 1. Respondent profile

\begin{tabular}{llcc}
\hline & \multicolumn{1}{c}{ Respondents } & Frequency & Percentage \\
\hline \multirow{3}{*}{ Gender } & Male & 87 & $(87 \%)$ \\
& Girl & 13 & $(13 \%)$ \\
\multirow{4}{*}{ Age } & $25-35$ years old & & \\
& over 35-40 & 22 & $(22 \%)$ \\
& over 40-45 & 18 & $(18 \%)$ \\
& over 45 years & 29 & $(29 \%)$ \\
\multirow{5}{*}{ Occupation } & Government employees & 31 & $31 \%$ \\
& Public Company employees & 30 & $(30 \%)$ \\
& & 10 & $(10 \%)$ \\
\hline
\end{tabular}




\begin{tabular}{llcc}
\hline \multicolumn{1}{c}{ Respondents } & Frequency & Percentage \\
\hline \multirow{5}{*}{ Income } & Private Company employees & 20 & $(20 \%)$ \\
& Entrepreneur & 25 & $(25 \%)$ \\
& College students & 10 & $(10 \%)$ \\
& Housewife & 5 & $(5 \%)$ \\
& Less than Rp. 1,500,000 & 13 & $13 \%$ \\
& Rp. 1,500,000 - Rp.2,000,000 & 5 & $5 \%$ \\
& over Rp. 2. 000,000 - Rp. 3,000,000 & 20 & $20 \%$ \\
& over Rp. 3,000,000 - Rp. 4,000,000 & 32 & $32 \%$ \\
over Rp. 4,000,000 & 30 & $30 \%)$ \\
\hline
\end{tabular}

\subsection{Hypothesis Testing}

Regression analysis is used to determine the effect of price variables , product design, product quality and brand image on purchase decisions. Here are the results of multiple regression analysis:

Table 2. Regression analysis results

\begin{tabular}{lccc}
\hline \multicolumn{1}{c}{ Variable } & $\begin{array}{c}\text { Standardized } \\
\text { Coefficients (Beta) }\end{array}$ & $\mathrm{t}$ & Sig. \\
\hline Price (X1) & 0,233 & 2,403 & 0.011 \\
Product design (X2) & 0,273 & 2.900 & 0.004 \\
Product quality (X3) & 0,262 & 2.798 & 0.005 \\
Brand Image (X4) & 0,222 & 0,612 & 0,027 \\
F statistic & 21,987 & & 0,000 \\
R & \multicolumn{2}{c}{0,682} & \\
Adjusted R Square & \multicolumn{2}{c}{0,449} \\
\hline
\end{tabular}

Table 2 displays the results of the regression analysis, it can be interpreted that all hypotheses can be accepted because the significance value is below 0.05 . The analysis results show that prices will improve consumer purchase decisions. The results of this study support the research carried out by Wibowo and Karimah (2012), they stated their research that price influences purchase decisions. It is in the same way as explained by Dharmmesta and Irawan (2002) that consumer purchase decisions depend on the price set by the producer.

The attractive product design will improve consumer purchase decisions. The results of this study support the previous research conducted by Saidani, et al (2013). As explained by Kotler (2000), the frequent demand expressed by the consumers is the demand for unique and creative product design. So it can be said that product design is a factor considered by consumers in purchasing. The result of this study presents that the better quality of the product, the more purchase decisions intended by the consumers. This study support the previous research conducted by Handri (2005). According to Handri (2005), there were $56.31 \%$ of respondents stated that their purchase decisions are affected by the product quality they buy. Tjiptono (1997) described that when the consumers were buying the products, they usually paid attention to the quality of the products offered whether they were related to the expected benefits or not. If the product quality is in line with expectations, the consumers will definitely buy the product and vice versa. Better brand image will be a magnet for a consumer in purchasing the product. The results of this study support the research conducted by Saidani and Ramadan (2013). They explained that the product image had an effect on the purchase decision. It is also explained by Kandampully \& Suhartono (2000) that the experience of 
consumers in dealing with service providers or products either directly or indirectly will affect the image of those providers. The influence of experience dealing with an organization is shaping consumer perceptions of an organization.

\section{Conclusion}

Based on the results of the analysis that has been carried out, it can be concluded that the price, product design, product quality and brand image variables significantly influence the purchasing decision of Scoopy motorcycles in Yogyakarta partially. Based on the results of research, the company needs to continue to maintain the quality of the products so that consumers can feel the satisfaction and are willing to come back and repurchase. The next researcher is expected to be able to conduct research on mobile phones or other products.

\section{References}

[1] F. Tjiptono, "Strategi Pemasaran Edisi Ketiga.” Penerbit Andi, Yogyakarta, 2000.

[2] M. Rizan, M. O. Nauli, and S. Mukhtar, "The influence of brand image, price, product quality and perceive risk on purchase decision transformer product PT. Schneider Indonesia,” JRMSI-Jurnal Ris. Manaj. Sains Indones., vol. 8, no. 1, pp. 101-119, 2017.

[3] B. Saidani, M. A. Rachman, and M. Rizan, "Pengaruh kualitas produk dan desain produk terhadap keputusan pembelian sepatu olahraga futsal adidas di wilayah Jakarta Timur,” JRMSI-Jurnal Ris. Manaj. Sains Indones., vol. 4, no. 2, pp. 201-217, 2013.

[4] J. Kandampully and D. Suhartanto, "Customer loyalty in the hotel industry: the role of customer satisfaction and image," Int. J. Contemp. Hosp. Manag., vol. 12, no. 6, pp. 346-351, 2000.

[5] H. Kusuma, "Manajemen Produksi: Perencanaan dan Pengendalian Produksi," Yogyakarta Andi, 2009.

[6] N. Ahmad, M. Billoo, and A. A. Lakhan, "Effect of product packaging in consumer buying decision," J. Bus. Strateg., vol. 6, no. 2, pp. 1-10, 2012.

[7] D. L. Goestsch and S. Davis, "Introduction to total quality: quality, productivity, competitiveness." New Jersey: Englewood, Cliffs Prentice Hall International, Inc, 1994.

[8] J. A. Howard, Consumer behavior in marketing strategy. Prentice Hall, 1989.

[9] P. Kotler and G. Armstrong, Principles of marketing. Pearson education, 2010.

[10] L. Hatani, "Manajemen pengendalian mutu produksi roti melalui pendekatan statistical quality control (SQC)," J. Jur. Manaj. FE UNHALU, vol. 1, pp. 1-7, 2008.

[11] I. D. Kurniasih, "Pengaruh Harga Dan Kualitas Pelayanan Terhadap Loyalitas Pelanggan Melalui Variabel Kepuasan (Studi Pada Bengkel Ahass 0002-Astra Motor Siliwangi Semarang)," J. Adm. Bisnis, vol. 1, no. 1, 2012.

[12] P. Kotler, "Manajemen Pemasaran Edisi Milenium," Jakarta: Prenhallindo, 2002.

[13] P. Kotler and G. Armstrong, Prinsip-prinsip pemasaran, vol. 1. Jilid, 2008.

[14] F. Tjiptono and A. Diana, "Total Quality Management Edisi Revisi," Yogyakarta Andi, 2003.

[15] P. Kotler and G. Armstrong, "Prinsip-prinsip Pemasaran, Jilid 1," Jakarta: Erlangga, 2008.

[16] W. J. Stanton and Y. Lamarto, "Prinsip Pemasaran Jilid 1," Erlangga. Jakarta, 1993.

[17] D. L. Goetsch and S. Davis, Quality management: Introduction to total quality management for production, processing, and services. Prentice Hall, 2006. 
[18] A. Ahyari, "Manajemen Produksi dan Pengendalian Produksi," Yogyakarta, BFE, 2002.

[19] H. Semuel and N. Wijaya, "Service quality, perceive value, satisfaction, trust, dan loyalty pada PT. Kereta Api Indonesia menurut penilaian pelanggan Surabaya," $J$. Manaj. Pemasar., vol. 4, no. 1, pp. 23-37, 2009.

[20] D. Amanah, "Pengaruh harga dan kualitas produk terhadap kepuasan konsumen pada majestyk bakery \& cake shop cabang HM Yamin Medan," J. Keuang. bisnis, vol. 2, no. 1, pp. 71-87, 2010.

[21] S. F. Wibowo and M. P. Karimah, "Pengaruh iklan televisi dan harga terhadap Keputusan Pembelian Sabun Lux (survei pada pengunjung Mega Bekasi Hypermall)," JRMSI-Jurnal Ris. Manaj. Sains Indones., vol. 3, no. 1, pp. 1-15, 2012.

[22] B. H. Brata, S. Husani, and H. Ali, "The Influence of Quality Products, Price, Promotion, and Location to Product Purchase Decision on Nitchi At PT. Jaya Swarasa Agung in Central Jakarta," Saudi J. Bus. Manag. Stud., vol. 2, no. 4, pp. 357-374, 2017.

[23] U. Sekaran and R. Bougie, Research methods for business: A skill building approach. John Wiley \& Sons, 2016.

[24] P. Sugiyono, "Metode Penelitian Kuantitatif, Kualitatif, dan R\&D," Metod. Penelit. Kuantitatif, Kualitatif, dan R\&D. Bandung CV Alf., 2010.

[25] L. J. Moleong, "Metodologi Penelitian Kualitatif Edisi Revisi, Cetakan keduapuluh dua, Bandung: PT," Remaja Rosdakarya Offset, 2006.

[26] S. Azwar, "Metode Penelitian; Penelitian Sebagai Kegiatan Ilmiah," Yogyakarta: Pustaka Belajar, 1999.

[27] U. Sumarwan, "Perilaku konsumen: Teori dan penerapannya dalam pemasaran," Bogor Ghalia Indones., 2011. 